\title{
Effects of salinity on photosystem II activity and antioxidant enzymes in two Türkish barley cultivars
}

\author{
Ali Doğru ${ }^{1}$ and Serkan Canavar ${ }^{1}$ \\ ${ }^{1}$ Sakarya University
}

May 5, 2020

\begin{abstract}
The antioxidant activity and photosynthetic efficiency of two Türkish barley cultivars, Erginel-90 and Tokak 157/37, grown under $120 \mathrm{mM} \mathrm{NaCl}$, was studied. Photosynthetic and antioxidative changes were much more significant after 7 days of salt treatment. The photosynthetic apparatus of Tokak 157/37 was found to be more tolerant to salt stress as compared with Erginel-90, probably due to higher antioxidant activity, lower $\mathrm{H} 2 \mathrm{O} 2$ content and lower lipid peroxidation. After 7 days of salt treatment, Erginel-90 showed high value of the rate of accumulation of closed reaction centers (?V/?to) and dissipation energy flux per PSII reaction center (DIo/RC) while it is not changed in Tokak 157/37 as compared to control. SM, N, ?o, ETo/RC, SFIABS, ?o/(1-?o), performance index (PIABS), ?Ro and ?Ro were drastically lower than control in Erginel-90 under salt stress for 7 days, however, these parameters in Tokak 157/37 were very close to the values determined in control plants. Thus, on the basis of our results on two barley cultivars, we recommend the use of some JIP test parameters such as ?V/?to, SM, N, SFIABS, PI, ?Ro, PI and ?Ro for the detection of salt-induced changes and to test salt tolerance degree in barley cultivars.
\end{abstract}

\section{Hosted file}

Manuscript PCE.doc available at https://authorea.com/users/303894/articles/434134-effects-ofsalinity-on-photosystem-ii-activity-and-antioxidant-enzymes-in-two-t\%C3\%BCrkish-barleycultivars 